\title{
Implications of Different Household Cooking Energy on Indoor Air Quality in Urban and Semi-Urban Settlements in Imo, South Eastern Nigeria
}

\author{
1*UBUOH, EA; ${ }^{2}$ NWAJIOBI, B
}

\author{
${ }^{1}$ Department of Environmental Management and Toxicology, ${ }^{2}$ Department of Forestry and Environmental Management, College of Natural \\ Resources and Environmental Management, Michael Okpara University of Agriculture, Umudike, Abia State, Nigeria \\ *Corresponding Author Email: ubuohemmanuel@yahoo.com \\ Tel: +2348037639777
}

\begin{abstract}
Energy is a basic necessity of life for meeting domestic, social and industrial needs of man. But the use of some of the energy sources has created problems in indoor environment that requires urgent attention. This study assessed the indoor air quality status as regards the effect of different household cooking methods from the use of nonrenewable energy sources in parts of Imo State. The cooking methods sampled were firewood stove, kerosene stove, charcoal stove, electricity stove and gas cooker. Indoor air quality was measured by digital air analyzers of different models continuously for 24 hours. Data collected were subjected to ANOVA using the SPSS 12.0 software, and mean values separated with FLSD) at $\mathrm{P}<0.05$ as statistically significant. Results showed that $\mathrm{CO}$ and $\mathrm{PM}_{2.5}$ concentrations produced during the use of firewood stove in urban settlements recorded the mean $(313.94 \pm 21.77$ and $476.06 \pm 203.09$ and semi- urban settlement (320.48 \pm 25.03 and 562.38 \pm 174.87 . The overall mean indoor air pollutants in urban and semi-urban environment were in order of $: \mathrm{SO}_{2} \geq \mathrm{CO} \geq \mathrm{PM}_{2.5} \geq \mathrm{NO}_{2}$ respectively, with $\mathrm{CO}, \mathrm{SO}_{2}$ and $\mathrm{PM}_{2.5}$ being above the $100\left(\mu \mathrm{g} / \mathrm{m}^{3}\right), 80\left(\mu \mathrm{g} / \mathrm{m}^{3}\right)$ and $150\left(\mu \mathrm{g} / \mathrm{m}^{3}\right)$ NAQS-2006 IAQ. Indoor air qualities from cooking methods in urban and semi-urban are statistically different at $(\mathrm{P}<0.05)$ level. The findings further indicated that gas cooker and electric stove cooking methods have less harmful effects than fuel wood, charcoal and kerosene on the indoor air quality in the study area. This indicated that urban and semi-urban settlements were utilizing energy sources at the lower energy ladder, with fuel wood dominating. Based on the findings, cleaner energy sources should be used in order to reduce indoor air pollution in developing countries.
\end{abstract}

\section{DOI: https://dx.doi.org/10.4314/jasem.v22i5.23}

Copyright: Copyright $\odot 2018$ Ubuoh and Nwajiobi. This is an open access article distributed under the Creative Commons Attribution License (CCL), which permits unrestricted use, distribution, and reproduction in any medium, provided the original work is properly cited.

Dates: Received: 16 February 2018; Revised: 21 March: 2018; Accepted: 22 April 2018

Keywords: Cooking methods, Indoor air quality, Energy ladder

Worldwide, more than three billion people still burn wood, dung, coal and other traditional fuels inside their homes and the resultant indoor air pollution is responsible for more than 1.5 million deaths a year mostly of young children and their mothers who spend most of their time at home and in the kitchen (WHO,2010). A number of scholars such as Mudway et al. (2005), and Saha et al. (2005) inferred that long term exposure to high levels of smoke from burning biomass fuels leads to a host of respiratory diseases. These are significant obstacles towards the achievement of Millennium Development Goals (MDG) 4, 5 and 6 (WHO, 2010). In developing countries, indoor air pollution ranks 8 th in terms of risk factors contributing to overall diseases and deaths, 1.1 billion people are exposed to high levels of respirable particles. Over 3 million excess deaths due to indoor air pollution and 300,000 excess deaths due to urban air and rural pollution (Iyiegbuniwe, 2006). In Nigeria for instance, large population live in rural areas and fuel wood is the major source of energy for cooking and lighting (Uwaegbute, 2011), leading to the release of large amount of health damaging pollutants such as particulate matter, $\mathrm{SO}_{2}, \mathrm{CO}_{2}$ etc. into the air. Since women are primarily responsible for cooking especially in developing countries and their children often spend time with them while they are engaged in the cooking activities, women and young children are the most affected by indoor air pollutants (Banik, 2010). Based on the Disability Adjusted Life Years (DALYs) approach, which includes both years lived with illness or injury and years of life lost due to premature mortality, household air pollution from solid cook fuels was found to be the largest environmental risk factor and the third greatest risk factor overall for the global burden of disease, with $4.3 \%$ of global DALYs (95\% confidence interval of 3.4-5.3\%) from this source (Lim et al. 2012; Smith et al. 2014; WHO, 2016; Khan et al, 2017). Cooking in a household involve the use of solid fuel and nonsolid fuel (Staton and Harding, 2011; Alphonsus et al, 2014). The use of some solid fuels has been associated with indoor pollution and unsafe levels of toxic emission (Viegi et al, 2004; Staton and Harding, 
2011). Therefore, for an effective prevention and intervention against indoor pollution from household fuel, there is a need to identify the pattern of household cooking fuel for sustainable indoor air quality for man's survival in urban and rural settings (Owusu and Kuitunen, 2006; Ouedraogo, 2006). This research is to evaluate the impact of different household cooking methods on indoor air quality in the selected parts of Imo State, Nigeria in order to properly inform on household cooking methodology for a healthy and safe indoor air quality.

\section{MATERIALS AND METHODS}

Description of the study area: The climate is typical of a tropical humid climate. The mean annual rainfall is between $1990 \mathrm{~mm}$ to $2238 \mathrm{~mm}$, distributed over seven months rainy season period (April to October/November) with bimodal peaks in June and September. The mean daily maximum temperature averages $27^{\circ} \mathrm{C}$ all through the year, highest from February to April, with average relative humidity reaching $75 \%$ or above, particularly in the rainy season. The topography is that of Undulated dissected plains with minor hills. In the household, an "ideal" fuel preference ladder with biomass fuels at the bottom and kerosene and electric at the top exists (Leach, 1992). The fuel preference ladder is broken down into 3 categories: biomass fuels, transition fuels, and modern fuels. The biomass fuels are divided into two categories: dung and crop residue, fuel wood which is typical in Nigeria (Plate1). Dung and crop residue reside below fuel wood and are used when fuel wood is scarce. Biomass lies at the bottom of the ladder. On the next tier are transition fuels of charcoal and coal. The top tier consists of kerosene, electric, liquefied petroleum gas (LPG), solar, and wind according to Katie (2012).

Selection of the Study Locations:

Urban Environment: Owerri municipal lies between latitude $05^{\circ} 15^{\prime} \mathrm{E}$ and $05^{\circ} 30^{\prime} \mathrm{N}$ and longitude $07^{\circ} 00^{\prime}$ $\mathrm{E}$ and $07^{\circ} 15^{\prime} \mathrm{W}$ (Wikipedia, 2018).

Semi-Urban Environment: Aboh- Mbaise is located between latitude $5^{0} 27^{\prime} \mathrm{N}$ to $7014^{\prime} \mathrm{E}$ and longitude $5^{0}$ $45^{\prime} \mathrm{N}$ to $7^{0} 23^{\prime} \mathrm{E}$. The inherent complexity of the semiurban areas puts the traditional duality of rural and urban areas in question (Juyoung et al, 2015).

Air Quality Sampling Techniques. A combination of monitoring durations and techniques was used to determine the feasibility of multiple methods of assessing the primary cook's exposure to combustionrelated by products (Rupak et al., 2012). Area sampling of $\mathrm{CO}, \mathrm{NO}_{2}, \mathrm{SO}_{2}$, and $\mathrm{PM}_{2.5}$ occurred continuously for either 24 hours from 20 households randomly selected from urban and semi-urban locations with each having 10 households. Personal sampling of $\mathrm{PM}_{2.5}$ occurred during cooking periods of approximately 2 hours, during which personal continuous $\mathrm{CO}, \mathrm{NO}_{2}, \mathrm{SO}_{2}$ sampling also occurred. Materials used for the study include the digital air analyzers: $\mathrm{NO}_{2}$ gas monitor, model 1983=range NO$50 \mathrm{ppm}=$ Alarm $1077 \mathrm{~m}, \mathrm{CO}_{2}$ gas monitor model $1925 \mathrm{~h}$ Rang $=0.50 \mathrm{ppm}$ Alarm $=56 \mathrm{PPM}$ and $\mathrm{PM}_{2.5}$, $\mathrm{Pm}^{2} \mathrm{HAZ}-\mathrm{TM}$ particulate monitor, Range $=0.1-200$ $\mu \mathrm{g} / \mathrm{m}^{3}$, Alarm $=+0.0 \mathrm{ug} / \mathrm{m}^{3}, \mathrm{SO}_{2}$ gas monitor model 1964 H, Range 0.10 99m, Alarm $2.077 \mathrm{~m}$ air quality monitors. Instruments were handled 1.5 meters above the ground in all locations; in the primary cooking location, the monitor was placed 1 meter from the point in the kitchens for 24 hours. All the measured air qualities were compared with National Air Quality standards, 2006).

Statistical Technique: The data obtained in the investigation was compiled and analyzed using analysis of variance (ANOVA) at 5\% level of significance. Significantly different means were separated according to the method of Duncan, 1955, using SPPS 12.0 software.

\section{RESULTS AND DISCUSSION}

The concentration of the various pollutants $\mathrm{CO}, \mathrm{SO}_{2}$, $\mathrm{NO}_{2}$ and $\mathrm{PM}_{2.5}$ in the urban environment and semiurban environment varied with the household cooking methods (Table 1-2). Table 3 shows comparative assessment of effect of the Cooking Methods on IAQ in the Urban and Semi-urban environment.

Table 1 : The Statistical Summary and description of Cooking Methods on Indoor Air Quality in Urban Environment

\begin{tabular}{llcll} 
Cooking & \multicolumn{4}{c}{ Indoor Air Parameter $(\mathrm{IAP})\left(\mu \mathrm{g} / \mathrm{m}^{3}\right)$} \\
\cline { 2 - 5 } Methods & \multicolumn{1}{c}{$\mathrm{CO}$} & $\mathrm{SO}_{2}$ & $\mathrm{NO}_{2}$ & \multicolumn{1}{c}{$\mathrm{PM}_{2.5}$} \\
\hline Firewood stove & $313.94 \pm 21.77^{\mathrm{c}}$ & $287.16 \pm 53.17^{\mathrm{de}}$ & $19.10 \pm 4.91^{\mathrm{b}}$ & $476.06 \pm 203.09^{\mathrm{c}}$ \\
Kerosene Stove & $289.44 \pm 43.18^{\mathrm{c}}$ & $270.98 \pm 35.95^{\mathrm{d}}$ & $15.28 \pm 4.83^{\mathrm{ab}}$ & $17.34 \pm 9.54^{\mathrm{a}}$ \\
Charcoal stove & $303.08 \pm 20.64^{\mathrm{c}}$ & $313.94 \pm 17.14^{\mathrm{e}}$ & $15.54 \pm 4.93^{\mathrm{ab}}$ & $166.14 \pm 51.18^{\mathrm{b}}$ \\
Electric Stove & $77.92 \pm 4.81^{\mathrm{b}}$ & $198.44 \pm 26.91^{\mathrm{c}}$ & $11.22 \pm 1.40^{\mathrm{a}}$ & $17.68 \pm 3.74^{\mathrm{a}}$ \\
Gas Cooker & $46.70 \pm 5.41^{\mathrm{a}}$ & $149.22 \pm 36.96^{\mathrm{b}}$ & $9.58 \pm 1.83^{\mathrm{a}}$ & $10.48 \pm 1.69^{\mathrm{a}}$ \\
NAQS-2006 & $100\left(\mu \mathrm{g} / \mathrm{m}^{3}\right)$ & $80\left(\mu \mathrm{g} / \mathrm{m}^{3}\right)$ & $\left(80 \mu \mathrm{g} / \mathrm{m}^{3}\right)$ & $150\left(\mu \mathrm{g} / \mathrm{m}^{3}\right)$ \\
\hline abcde Means \pm SE with different superscripts in the same column are significantly different $(P<0.05)$
\end{tabular}


Table 2: The Statistical Summary and description of Cooking Methods on Indoor Air Quality in Semi-Urban environment

\begin{tabular}{lllll}
\hline Cooking & \multicolumn{4}{c}{ Indoor Air Parameter $(\mathrm{IAP})\left(\mu \mathrm{g} / \mathrm{m}^{3}\right)$} \\
\cline { 2 - 5 } Methods & $\mathrm{CO}$ & $\mathrm{SO}_{2}$ & $\mathrm{NO}_{2}$ & $\mathrm{PM}_{2.5}$ \\
Fire wood stove & $320.48 \pm 25.03^{\mathrm{d}}$ & $366.50 \pm 46.17^{\mathrm{c}}$ & $21.64 \pm 3.06^{\mathrm{b}}$ & $562.38 \pm 174.87^{\mathrm{c}}$ \\
Kerosene Stove & $289.44 \pm 43.18^{\mathrm{c}}$ & $308.98 \pm 53.71^{\mathrm{b}}$ & $15.50 \pm 2.60^{\mathrm{ab}}$ & $21.62 \pm 12.30^{\mathrm{a}}$ \\
Charcoal stove & $321.12 \pm 16.37^{\mathrm{d}}$ & $343.58 \pm 51.59^{\mathrm{bc}}$ & $17.02 \pm 3.20^{\mathrm{ab}}$ & $319.66 \pm 100.27^{\mathrm{b}}$ \\
Electric Stove & $82.54 \pm 8.10^{\mathrm{b}}$ & $61.02 \pm 22.00^{\mathrm{a}}$ & $11.62 \pm 1.67^{\mathrm{a}}$ & $12.72 \pm 2.62^{\mathrm{a}}$ \\
Gas Cooker & $50.84 \pm 3.48^{\mathrm{a}}$ & $37.52 \pm 7.27^{\mathrm{a}}$ & $10.76 \pm 1.21^{\mathrm{a}}$ & $10.48 \pm 1.44^{\mathrm{a}}$ \\
$\mathrm{NAQS}-2006$ & $100\left(\mu \mathrm{g} / \mathrm{m}^{3}\right)$ & $80\left(\mu \mathrm{g} / \mathrm{m}^{3}\right)$ & $\left(80 \mu \mathrm{g} / \mathrm{m}^{3}\right)$ & $150\left(\mu \mathrm{g} / \mathrm{m}^{3}\right)$ \\
\hline abcde Means \pm SE with different superscripts in the same column are significantly different $(P<0.05)$
\end{tabular}

Table 3. Comparative assessment of effect of the Cooking Methods on IAQ in the Urban and Semi-urban environment

\begin{tabular}{lll}
\hline POLLUTANTS & \multicolumn{1}{c}{ ENVIRONMENT } \\
\cline { 2 - 3 } & $\operatorname{URBAN}\left(\mu \mathrm{g} / \mathrm{m}^{3}\right)$ & SEMI-URBAN $\left(\mu \mathrm{g} / \mathrm{m}^{3}\right)$ \\
\hline Carbon monoxide & $159.00 \pm 1.00^{\mathrm{c}}$ & $168.00 \pm 1.00^{\mathrm{c}}$ \\
Sulphur dioxide & $190.00 \pm 1.00^{\mathrm{d}}$ & $174.00 \pm 1.00^{\mathrm{d}}$ \\
Particulate matter & $113.00 \pm 1.00^{\mathrm{b}}$ & $145.00 \pm 1.00^{\mathrm{b}}$ \\
Nitrogen dioxide & $2.75 \pm 0.01^{\mathrm{a}}$ & $25.00 \pm 1.00^{\mathrm{a}}$ \\
\hline abcd Means \pm SE with different superscripts in the same row are significantly different $(P<0.05)$
\end{tabular}

Firewood stove produced the highest amount of $\mathrm{CO}$ (313.94 \pm 21.77$), \mathrm{NO}_{2}(19.10 \pm 4.91)$, and particulate matter (476.06 \pm 203.09$)$, while charcoal stove recorded the highest $\mathrm{SO}_{2}(313.94 \pm 17.14)$ of all the cooking methods. The there was no significant differences in $\mathrm{CO}$ produced by Firewood stove, kerosene stove and Charcoal stove; the $\mathrm{CO}$ produced by the trio was significantly higher than that produced by electric stove and gas cooker. The gas cooking method produced least of all four pollutants $\left(\mathrm{CO}_{2}\right.$, $\mathrm{SO}_{2}, \mathrm{NO}_{2}$ and $\mathrm{PM}_{2.5}$ ) with values of 46.70 \pm 5.41 , $149.22 \pm 36.96,9.58 \pm 1.83,10.48 \pm 1.69$ respectively, which was significantly less than the amounts produced by Firewood stove for all four pollutants, Kerosene stove for $\mathrm{CO}_{2}$ and $\mathrm{SO}_{2}$, Charcoal stove for $\mathrm{CO}, \mathrm{SO}_{2}$ and $\mathrm{Pm}_{2.5}$; and Electric stove for $\mathrm{CO}$ and $\mathrm{SO}_{2}$ respectively (Table 1). There was significant difference in the amount of the various indoor air quality (IAQ) from the different cooking methods in the semi-urban environment. Fire wood stove cooking method recorded the highest levels of all the pollutants including

$\mathrm{CO}$ (320.48 \pm 25.03$), \mathrm{SO}_{2}(366.50 \pm 46.17), \mathrm{NO}_{2}(21.64 \pm 3.06)$ , and $\mathrm{PM}_{2.5}(562.38 \pm 174.87)$. The least values were recorded in the gas cooker method with values of $50.84 \pm 3.48,37.52 \pm 7.27,10.76 \pm 1.21$, and $10.48 \pm 1.44$ respectively. Of the four pollutants, only with regards to particulate matter was the amount produced by firewood stove recorded $(562.38 \pm 174.87)$ significantly different from that produced by Charcoal stove $(319.66 \pm 100.2)$ (Table 2). From Table 3, the findings indicated that pollutants from different cooking methods in urban and semi-urban environment were statistically different in their individual rows. The result indicate that the gas cooker and electric Stove cooking methods are more environmentally friendly cooking methods (Fig. 1).
The overall mean indoor air pollutants (IAP) in urban environment were in order of viz: $\mathrm{SO}_{2} \geq \mathrm{CO}$ $\geq \mathrm{PM}_{10} \geq \mathrm{NO}_{2}$ (Table 1).

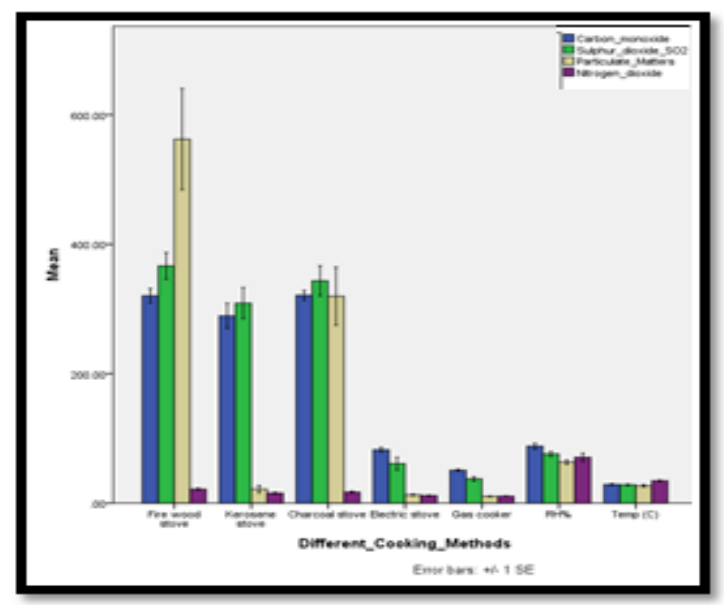

Fig 1: Mean Concentration of Indoor Air Pollutants from Different Cooking Methods in the Urban Environment

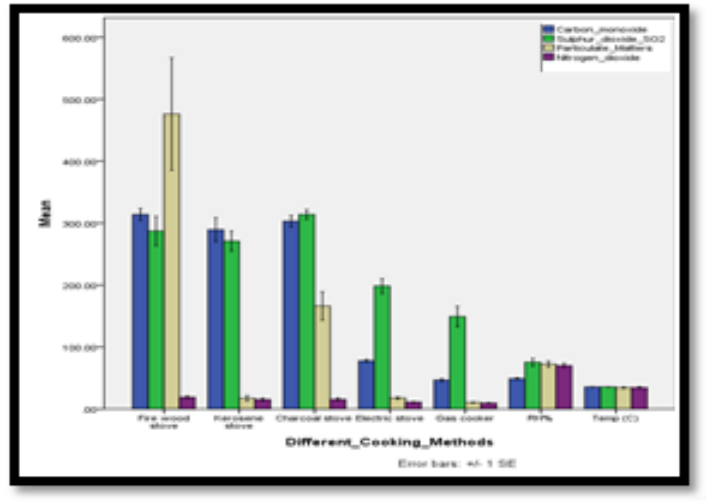

Fig 2: Mean Concentration of Indoor Air Pollutants from Different Cooking Methods in the Semi-Urban Environment 
The Electric stove cooking method followed the Gas cooker method with respect to producing the least amounts of all the pollutants (Fig. 2). The overall mean indoor air Pollutants from the semi-urban environment were in order of : $\mathrm{SO}_{2} \geq \mathrm{CO} \geq \mathrm{PM}_{10} \geq \mathrm{NO}_{2}$ (Table 2). The result agreed with the report that firewood produced high amount of indoor pollutants and so is a major risk factor for Acute Respiratory Infections (AR) (WHO, 2007; Fullerton et al, 2008). From the comparative studies made, firewood, kerosene and charcoal stove emitted $\mathrm{CO}$ above the NAQS-2006, all the cooking methods emitted $\mathrm{SO}_{2}$ above the standard, while firewood and charcoal emitted P.M $\mathrm{M}_{2.5}$ above the standard in urban environment sampled.

The study focused of the effect of different cooking methods on indoor air quality in part of Imo State. The results showed that in urban settlement, gas cooking produced least of all four pollutants, which was significantly less than the amounts produced by Firewood stove for all the four pollutants; Kerosene stove : $\mathrm{CO}_{2}$ and $\mathrm{SO}_{2}$, Charcoal stove : $\mathrm{CO}, \mathrm{SO}_{2}$ and $\mathrm{Pm}_{2.5}$; and Electric stove for $\mathrm{CO}$ and $\mathrm{SO}_{2}$ respectively. In semi urban settlement, the results also indicated that, fire wood stove recorded the highest levels of all the pollutants. The least values were recorded in the gas cooker. The result agreed with Goldenberg (2000) who reported that the use of firewood as source of heating and energy for cooking and lighting causes indoor air pollution and exposes families to air pollution levels as much as 50 times greater than World Health Organization guidelines for clean air, setting the stage for heart and lung disease. Of the four pollutants measured, only with regards to particulate matter was the amount produced by firewood stove recorded was significantly different from that produced in Charcoal stove. Accordingly, the overall mean indoor air Pollutants from the urban and semi-urban environments were in order of $\mathrm{SO}_{2} \geq$ $\mathrm{CO} \geq \mathrm{PM}_{2.5} \geq \mathrm{NO}_{2}$ respectively. The results further indicated in urban and semi-urban locations, except electric stove and gas cooker, firewood, kerosene and charcoal stoves recorded $\mathrm{CO}$ above the National Air Quality Standard (NAQS-2006), the four cooking methods had $\mathrm{SO}_{2}$ emission above the NAQS, except electric and gas cooker in semi-urban with $\mathrm{NO}_{2}$ below the standard respectively. Particulate matter was emitted above the NAQS-2006 in firewood and charcoal stoves, while kerosene, electric stove and gas cooker emitted $\mathrm{PM}_{2.5}$ below the NAQS-2006 respectively. In semi-urban settlement, firewood, kerosene and charcoal stoves emitted $\mathrm{CO}$ and $\mathrm{SO}_{2}$ above the standard, with firewood and charcoal releasing P.M $\mathrm{M}_{2.5}$ above the standard respectively. Carboxy-hemoglobin $(\mathrm{COHb})$ from $\mathrm{CO}$ impairs the oxygen-carrying capacity of the blood, putting a strain on tissues with high oxygen demand, such as the heart and the brain (WHO, 1999, Varon et al, 1999). Studies on coal mining resulted to the emission of P.M $\mathrm{M}_{2.5}, \mathrm{CO}$, NOx and SOx that caused dizziness, headache, fatigue, and impaired judgment, lung irritation, bronchitis, pneumonia, asthma, respiratory infections, pulmonary edema and emphysema (Ghose and Majee, 2002; Sinha and Sreekesh, 2002; Suman et al., 2007). They also influence the functioning of brain and heart (Ubuoh and Ogbuji, 2016). From the results, $\mathrm{SO}_{2}, \mathrm{CO}$ and $\mathrm{PM}_{2.5}$ are mainly from using traditional cooking methods that are unclean at the lower energy ladder, leading to respiratory problems for women, children, elderly and degradation of the physical environment. The results further showed that indoor air quality from different cooking methods in urban and semi-urban environment were statistically different at $(\mathrm{P}<0.05)$ level of significant. The result is consistent with the findings of Cheong et al (2005), Selvaraj et al, (2014) who observed that household air pollutants from cooking activities are common in developing countries.

Conclusion: From the overall results of the study, households have access to using traditional cooking methods that are environmentally unfriendly energy sources at the lower energy ladder with fuel wood being the highest. It is now suggested that, households should be encouraged to use cleaner burning energy to reduce indoor air pollution in urban and semi-urban environment. Uses of fuel wood for domestic energy needs should be discouraged in order to protect the nation's forest resources with a view to reduce global warming and menace of soil erosion.

\section{REFERENCES}

Alphonsus, RI; Adesuwa, QA (2014). Household Cooking Fuel Use among Residents of a Sub-Urban Community in Nigeria: Implications for Indoor Air Pollution. Eurasian J Med; 46: 203- 208.

Banik, BK (2010). Female perceptions of health hazards associated with indoor air pollution in Bangladesh. Int J Sociol Anthropol. 2(9):206

Cheong, KW; Yu, WJ; Tham, KW; Sekhar, SC.; Kosonen, R (2005). A Study of Perceived Air Quality and Sick Building Syndrome in A Field Environment Chamber Served by Displacement Ventilation System in The Tropics. Journal of Building and Environment 41: 1530-1539

Fullerton, DG; Bruce, N.; Gordon, SB (2008). Indoor air pollution from biomass fuel smoke is a major health concern in the developing world. Trans $R$ Soc Trop Med Hyg. 102 (9):843-51.

Ghose, MK.; Majee, SR (2002). Assessment of the status of work zone air environment due to opencast coal mining. Environ. Monit. Assess. 77: 51-60. 
Goldenberg, J (2000). Rural Energy in Developing Countries. In: W orld Energy Assessment: Energy and the Challenge of Sustainability. UNDP. NY.

Iyiegbuniwe, AI (2006). Environmental Air Quality Exposure Assessment in a Rural Nigerian Village. Western Kentucky University Bowling Green, KY 42101 AIHce 2006, Podium 111.

Juyoung, L.; Bum-Jin, P. ; Tatsuro, O.; Takahide, K.; Yoshifumi, MI(2015. Acute Effects of Exposure to a Traditional Rural Environment on Urban Dwellers: A Crossover Field Study in Terraced Farmland. Environ. Res. Public Health, 12(2), 1874-1893.

Katie, MP (2012). Fuelwood collection and consumption: a case study in Lupeta, Tanzania. A THESIS Submitted in partial fulfillment of the requirements for the degree of Master of Science in Forestry Michigan Technological University.

Khan, MN; Nurs, CZ; Islam, MM; Islam, MR.; Rahman, MM (2017). Household air pollution from cooking and risk of adverse health and birth outcomes in Bangladesh: a nationwide population based study. Environmental Health (2) 16:57.

Leach, G (1992). The energy transition. Energy Policy. 20(2): 116-123.

Lim, SS.; Vos, AD.; Flaxman, G.; Danaei, K.; Shibuya, H.; Adair-Rohani, M.; Amann, HR (2012). "A Comparative Risk Assessment of Burden of Disease and Injury Attributable to 67 Risk Factors and Risk Factor Clusters in 21 Regions, 1990-2010. Lancet 380(9859).

Mudway, IS.; Duggan, ST.; Venkataraman, C.; Habib, G.; Kelly, FJ.; Grigg, J (2005). Combustion of dried animal dung as biofuel results in the generation of highly redox active fine particulates. Particle and Fibre Toxicology, 2(6), 1-11

National Ambient Air Quality Standards (NAQS). (2006). National Ambient Air Quality Standards (NAAQS) for air quality. Environmental Protection Agency. Retrieved 2017-06-28.

Ouédraogo, B (2006). Household energy preferences for cooking in urban Ouagadougou, Burkina Faso". Energy Policy, vol. 34 (18), Elsevier Ltd, Oxford, pp. 3787-3795,

Owusu, BK.; Kuitunen, M (2006). Factors affecting the choice of cooking fuel, cooking place and respiratory health in the Accra metropolitan area, Ghana. J Biosoc Sci. 38(3):403-412

Rupak, M.; Sankar, S.; Ajay, PI.; Darby, J.; Krishnendu, M.; Kalpana, B.; Mayur, V.; , Michael, NB.; Patrick, LK.; Narendra, A.; Smith, KR (2012). Cooking practices, air quality, and the acceptability of advanced cookstoves in Haryana, India: an exploratory study to inform large-scale interventions. Global Health Action 2012.

Saha, A., Rao, NM, Kulkarni, PK., Majumdar, K.; Saiyed, HN (2005). Pulmonary function and fuel use: A population survey. Respiratory Research, 6(127), 1-6.
Selvaraj, K.; ChinnakalI, P.; Majumdar, A.; Krishnan, IS (2014). Acute respiratory infections among under-5 children in India: a situational analysis. $J$ Nat Sci. Biol Med. 5(1):15.

Sinha, S; Sheekesh, S (2002). Air quality status and management options for the mining belt of Goa. Indian J. Environ. Prot. 22: 241-253.

Smith, KR.; Bruce, NK.; Balakrishnan, H.; AdairRohani, J.; Balmes, Z; Chafe, M. Dherani, HD.; Hosgood, S.; Mehta, D.; Pope, E (2014). Millions dead: how do we know and what does it mean? Methods used in the Comparative Risk Assessment of Household Air Pollution." Ann Rev of Public Health 35: 185-206

Staton, DM; Harding, MH (2011). Health and environmental effects of cooking stove use in developing countries. 2000. Cited 22-11-2011.

Suman, P.; Pal AK; Singh, G (2007). Assessment of air quality status in Angul-Talcher coal mining area in Orissa. In: Proc. Intl. Conf. MSECCMI, New Delhi, India. pp. 577-589.

Torres-Duque, C; Maldonado, D; Pérez-Padilla, R.; Ezzati, M.; Viegi, G. (2008). Forum of International Respiratory Studies (FIRS) Task Force on Health Effects of Biomass Exposure. Proc Am Thorac Soc. 2008; 5(5):577-590.

Ubuoh EA.; Ogbuji S. (2016): Analysis of the Atmospheric Compositions at Traffic Intersections on the Selected Major Roads in Imo State, Nigeria. CARD International Journal of Environmental Studies and Safety Research (IJESSR). Volume 1, Number 2, pp150-171.

Uwaegbute, AC (2011). Food security in Nigeria: Causes and consequences. In: Nwachukwu, I and Ekwe, K.C. (Eds.). Globalization and Rural Development in Nigeria. $74-98$.

Varon, J.; Marik, PE; Fromm, RE.; Gueler, A (1999). Carbon Monoxide Poisoning: A Review for Clinicians. The Journal of Emergency Med, 17: 8793.

Viegi, G.; Simoni, M.; Scognamigli, A.; Baldacci, S.; Pistelli, F.; Carrozzi, L (2004). Indoor air pollution and airway disease. Int J Tuberc Lung D 8(12):140115.

World Health Organization (WHO) (2007). Indoor air pollution. National burden of disease estimates. Vol. 2007. Geneva: WHO.

World Health Organization (WHO) (1999). Carbon Monoxide. Environmental Health Criteria 213. Geneva: World Health Organization.

World Health Organization (WHO) (2010). Health in the green economy: Household energy sector in developing countries. Public Health and Environment Department

World Health Organization (WHO) (2016). Ambient air pollution: A global assessment of exposure and burden of disease. Public health, environmental and social determinants of health (PHE), Geneva, Switzerland: WHO. 